\title{
PENGARUH SEDIAAN SALUT DAN PUPUK ORGANIK CAIR TERHADAP PERTUMBUHAN DAN HASIL KEDELAI (Glycine max L. Merril)
}

\author{
Erlinda, Jamilah*, Welly Herman \\ Program Studi Agroteknologi Fakultas Pertanian Universitas Tamansiswa Padang \\ *Email:jamilah@unitas-pdg.ac.id
}

\begin{abstract}
Abstrak
Penelitian ini bertujuan untuk mengetahui interaksi pengaruh Sediaan Salut dan Pupuk Organik Cair Unitas Super terhadap pertumbuhan dan hasil kedelai (Glycine max.L Merril). Penelitian ini menggunakan rancangan acak lengkap yang disusun secara faktorial dengan 2 perlakuan dan 3 ulangan. Faktor pertama sediaan salut terdiri atas 2 taraf yaitu tanpa salut SO (kontrol) dan S1 $(1 \mathrm{~kg}$ tanah $+1 \mathrm{~kg}$ kompos $+100 \mathrm{gr}$ kapur $+0,5 \mathrm{~kg}$ tanah bekas tanam kedelai +10 gr pupuk PK $)$, faktor ke 2 adalah aplikasi POC yang terdiri atas 4 taraf yaitu $0 \mathrm{ml} / \mathrm{L}, 10 \mathrm{ml} / \mathrm{L}, 20 \mathrm{ml} / \mathrm{L}, 30 \mathrm{ml} / \mathrm{L}$. Hasil penelitian yang telah dilakukan menunjukkan bahwa pemberian tanpa Salut dan POC US pada taraf $30 \mathrm{ml} / \mathrm{L}$ dapat meningkatkan tinggi tanaman, rasio tajuk akar, dan bobot 100 biji.
\end{abstract}

Key words : kedelai, salut, pupuk organik cair

(C) 2019 Erlinda, Jamilah, Welly Herman

\section{PENDAHULUAN}

Kedelai merupakan salah satu komoditas tanaman pangan yang memegang peranan penting setelah beras disamping sebagai bahan pakan dan industri olahan di Indonesia. Karena kedelai hampir 90\% digunakan sebagai bahan pangan maka ketersediaan kedelai menjadi faktor yang cukup penting (Anonimous, 2004). Selain itu kedelai juga merupakan tanaman palawija yang kaya akan protein, yang memiliki arti penting sebagai sumber protein nabati untuk peningkatan gizi dan mengatasi penyakit kurang gizi seperti busung lapar. Perkembangan manfaat kedelai disamping sebagai sumber protein, makanan berbahan kedelai dapat juga sebagai penurun kolesterol darah yang dapat mencegah penyakit jantung. Selain itu kedelai dapat berfungsi sebagai antioksidan dan dapat mencegah kanker. Oleh karena itu kedepan proyeksi kebutuhan kedelai akan meningkat seiring dengan kesadaran masyarakat tentang makanan sehat.

Produksi kedelai sebagai bahan olahan pangan berpotensi dan berperan dalam menumbuh kembangkan industri kecil menengah bahkan sebagai komoditas ekspor.
Kebutuhan kedelai pada tahun 2004 sebesar 2,04 juta ton, sedangkan produksi dalam negeri baru mencapai 0,71 juta ton dan kekurangannya diimpor sebesar 1,31 juta ton (Anonimous, 2005c). Hanya sekitar 35\% dari total kebutuhan dapat dipenuhi dari produksi dalam negeri sendiri. Upaya untuk menekan laju impor tersebut dapat ditempuh melalui strategi peningkatan produktivitas, perluasan area tanam, peningkatan kualitas produk , peningkatan nilai tambah, perbaiakan akses pasar, perbaikan sistem permodalan, pengembangan infra struktur, serta pengaturan tata niaga dan insentif usaha (Anonimous, 2005c). Mengingat Indonesia dengan jumlah penduduk yang cukup besar, dan industri pangan berbahan baku kedelai berkembang pesat. Maka komoditas kedelai perlu mendapat prioritas untuk dikembangkan di dalam negeri untuk menekan laju impor (Anonimous, 2005b).

Kebutuhan akan kedelai dalam negeri semakin meningkat untuk setiap tahunnya, peningkatan ini seiring dengan peningkatan jumlah penduduk, populasi ternak serta peningkatan kebutuhan industri. Untuk pencapaian pemenuhan kebutuhan tersebut 
pemerintah mengimpor dari beberapa Negara penghasil kedelai didunia. Penduduk Indonesia mengkonsumsi kedelai mencapai 2,2 juta ton per tahun, sedangkan produksi kedelai Indonesia baru memenuhi 30\% dari kebutuhan tersebut. Akibatnya Indonesia harus mengimpor kebutuhan yang kurang $70 \%$ atau lebih dari 2 juta per tahun, pada tahun 2015 sudah mencapai 2,26 juta ton. Pada tahun 2016 kondisi kedelai belum mencerahkan, salah satu sebab import yang tinggi banyak petani mengutamakan menanam padi dan jagung. Kementrian Pertanian (2016) menyatakan produksi kedelai menurun hingga 77,61 ribu ton dibandingkan tahun 2015.

Permasalahan hasil kedelai yang rendah terutama di tanah masam Ultisol, disamping varietas yang kebanyakan berproduksi hanya $<2 \mathrm{t} /$ ha juga yang tak bisa dipungkiri adalah masalah kesuburan tanah. Fenomena ini terjadi karena beberapa faktor, salah satunya disebabkan oleh rendahnya produktifitas kedelai ditambah dengan biaya produksi yang tinggi sehingga sulit untuk mengimbangi permintaan, padahal sebenarnya dengan melihat potensi yang ada produksi masih bisa ditingkatkan. Salah satu upaya yang mungkin dilakukan adalah menghasilkan varietas baru yang mempunyai produksi tinggi dan juga mempunyai kemampuan tumbuh dan berkembang dengan baik. Dari beberapa varietas kedelai yang sudah dirilis dan tergolong kategori unggul, ada satu varietas yang bernama Baluran yang berpotensi bisa menghasilkan $>3$ t/ha (Anonim, 2017).

Teknologi yang sudah dikembangkan dalam mengatasi permasalahan tingginya kelarutan Aluminium dan $\mathrm{pH}$ yang rendah antara lain : memberikan kapur setara $2 \times \mathrm{Al}-$ dd mencapai 3-6, berarti ada sebanyak $6-8$ t/ha $\mathrm{CaCO}_{3}$ yang diberikan (Hakim et al, 1986: 1989). Jika harga kapur $\mathrm{CaCO}_{3}$ mencapai $\mathrm{Rp}$ $600 / \mathrm{kg}$, maka ongkos usaha tani yang harus dikeluarkan khusus untuk pengadaan kapur minimal 3,6 juta rupiah. Oleh sebab itu perlu ada upaya yang efektif dan efisien dilakukan agar ongkos usaha tani dapat dipangkas semaksimal mungkin, dan hasil kedelai juga meningkat.
Ada beberapa hal yang harus diperhatikan agar produktifitas kedelai meningkat, agar ongkos usaha tani bisa ditekan pekerjaanya lebih praktis dan mudah yaitu dengan membuat sediaan salut. Sediaan salut adalah suatu campuran antara bahan tanah liat asal Ultisol, kompos atau pupuk kandang, kapur, legin atau tanah bekas tanam kedelai dan pupuk buatan diaduk berdasarkan komposisi tertentu sebagai selaput (coated) benih. Pengadaan Sediaan salut terinspirasi dari kebiasaan orang zaman dahulu yang menggelimangkan benih pada tanah bekas tanam kedelai untuk menginokulasi bakteri rhizobium pada benih kedelai sebagai perlakuan pra tanam (seed treatment).

Penyelaputan benih kedelai dengan bahan tanah yang bernutrisi masih belum populer dilakukan. Pekerjaan ini sebenarnya sangat mudah dan menguntungkan karena hemat ongkos usaha tani. Penyelaputan (coated) pada benih kedelai bisa dilakukan dengan cara yang aman, dan tidak mengganggu metabolisme tanaman. Kegiatan ini diharapkan akan menghasilkan benih tumbuh lebih survive dibandingkan tanaman yang tidak diperlakukan, dan masih belum lazim dilakukan pada budidaya kedelai. Diharapkan sediaan salut sungguh-sungguh dapat meningkatkan hasil kedelai pada tanah Ultisol, disamping itu juga bisa menghemat penggunaan pupuk buatan.(Hakim, 2006)

Sediaan salut diharapkan bisa menjadi suatu formula ramuan bagi perlakuan seed treatment yang dapat diformulasikan sebagai produk paten. Di samping pengadaan sediaan salut, unsur hara diberikan jauh lebih praktis dan hemat melalui aplikasi pupuk organik cair (POC) yang berasal dari berbagai ramuan bahan organik, antara lain :Chromolaena odorata, pupuk kandang, urine sapi, sabut kelapa, MOL (buah papaya + air kelapa). Penggunaan POC tersebut sudah banyak diteliti oleh (Jamilah dan Novita, 2016) pada tanaman bawang (Jamilah, Soleh dan Herman, 2017): (Jamilah dan Helmawati, 2015a): (Jamilah, Napitupulu, dan Marni, 2013): (Jamilah, Fadhila, dan Mulyani, 2017): (Jamilah, 2016): (Jamilah, Juniarti, dan Srimulyani, 2016) 
tanaman padi sawah: (Jamilah dan Permana, 2015) pada tanaman stroberi. Secara umum hasil produksi tanaman meningkat hingga 29\%. Pengayaan POC dengan berbagai mikroorganisme yang bersifat pengendali hayati dan menyuburkan tanah belum diuji keunggulannya, terutama pada tanaman kedelai. Oleh sebab itu perlu diketahui peranan POC dalam memenuhi kebutuhan hara tanaman kedelai.

Menurut Jamilah dan Fatimah, (2008) tanaman yang diberi POC tersebut lebih cocok jika tanahnya bermasalah yang mengakibatkan akar kurang mampu menyerap unsur hara pada waktu yang tepat. Aplikasi POC sangat praktis dan ekonomis dan dapat meningkatkan penyerapan hara hingga 4 kali lebih besar. Pengayaan POC dengan berbagai mikroorganisme yang bersifat pengendali hayati dan menyuburkan tanah belum diuji keunggulannya, terutama pada tanaman kedelai. Oleh sebab itu perlu diketahui peranan POC dalam memenuhi kebutuhan hara tanaman kedelai. Hasil yang akan dicapai antara lain : formula sediaan salut, komposisi sediaan salut yang tepat, POC konsorsia yang dinyatakan sebagai teknologi pemupukan terpadu minimalis pada tanah masam yang bermasalah dalam upaya pengematan ongkos usaha tani dan meningkatkan hasil kedelai.

Pemupukan terpadu minimalis adalah rekomendasi pemupukan intensifikasi untuk kedelai berpotensi hasil tinggi dapat disusun sesuai dengan status hara $\mathrm{P}$ dan $\mathrm{K}$ tanah dan kebutuhan tanaman akan hara. Dengan diterapkannya teknologi pengelolaan tanah, air dan pemupukan yang tepat maka produktivitas kedelai dilahan intensifikasi.

Tujuan dari penelitian ini adalah Untuk mengetahui interaksi antara sediaan salut dan POC terhadap pertumbuhan dan hasil tanaman kedelai, mengetahui pengaruh pemberian sediaan salut terhadap pertumbuhan dan hasil tanaman kedelai, dan mengetahui pengaruh pemberian POC terhadap pertumbuhan dan hasil kedelai

\section{BAHAN DAN METODA}

Penelitian ini dilaksanakan mulai bulan Februari 2018 sampai Juni 2018 di rumah kawat Fakultas Pertanian Universitas Andalas Padang, terletak pada ketinggian $250 \mathrm{~m}$ dpl. Tanah yang digunakan berordo Ultisols dan tanaman kedelai dengan varietas Anjasmoro. Penelitian dilaksanakan secara eksperimen menggunakan Rancangan Acak Lengkap Faktorial (RAL). Yang terdiri dari 2 faktor perlakuan yaitu faktor pertama(1) adalah komposisi sediaan salut yaitu ; S0 (kontrol), $\mathrm{S} 1(1 \mathrm{~kg}$ tanah $+1 \mathrm{~kg}$ kompos $+100 \mathrm{~g}$ kapur $\mathrm{CaCO}_{3}+0,5 \mathrm{~kg}$ tanah bekas tanam kedelai + $10 \mathrm{~g}$ pupuk PK. Faktor kedua adalah ; Aplikasi POC Unitas Super diperoleh dari Fakultas Pertanian Universitas Tamansiswa yang terdiri atas 4 taraf yaitu ; $0 \mathrm{ml} / \mathrm{L} ; 10 \mathrm{ml} / \mathrm{L} ; 20 \mathrm{ml} / \mathrm{L}$; dan $30 \mathrm{ml} / \mathrm{L}$. Percobaan diulang sebanyak 3 kali.

Pengamatan yang dilakukan adalah tinggi tanaman, jumlah cabang pertanaman, bintil akar efektif, rasio bobot kering tajuk akar, persentase polong bernas, bobot 100 biji, berat pipilan kering pertanaman. Hasil pengukuran diolah secara statistik mengunakan uji lanjut DNMRT pada taraf 5\%.

\section{HASIL DAN PEMBAHASAN}

\section{A. Tinggi Tanaman}

Hasil analisis sidik ragam perlakuan pengaruh sediaan salut dan pupuk cair organik memperlihatkan interaksi sangat nyata terhadap tinggi tanaman kedelai, sedangkan perlakuan sediaan salut berpengaruh sangat nyata dan pupuk cair organik berpengaruh sangat nyata terhadap tinggi tanaman kedelai seperti pada lampiran 5A tinggi tanaman disajikan pada Tabel 1 .

Tabel 1. memperlihatkan bahwa tanpa pemberian sediaan salut dan peningkatkan dosis POC US akan menyebabkan tinggi tanaman kedelai semakin tinggi. Tanpa pemberian sediaan salut pengaruh yang sangat nyata terhadap peningkatan tinggi tanaman seiring dengan meningkatnya dosis POC US yang diberikan, yaitu dosis $30 \mathrm{ml} / 1$ memberikan tinggi tanaman tertinggi, yaitu $106,33 \mathrm{~cm}$. Hal ini disebabkan karena komposisi unsur hara yang terdapat pada POC 
US lengkap, baik itu kandungan makro maupun mikro yang sangat dibutuhkan oleh tanaman untuk pertumbuhannya (Jamilah dan Permana).

\section{B. Jumlah Cabang Per-tanaman}

Hasil analisis sidik ragam perlakuan sediaan salut dan pupuk organik cair memperlihatkan berinteraksi tidak nyata terhadap jumlah cabang tanaman kedelai. Sedangkan perlakuan sediaan salut berpengaruh nyata terhadap jumlah cabang per tanaman akan tetapi dosis POC tidak berpengaruh terhadap jumlah cabang seperti pada lampiran 5B. Jumlah cabang per tanaman disajikan pada Tabel 2 .

Tabel 1. Pengaruh sediaan salut dan POC US terhadap tinggi pada tanaman kedelai (Glycine max L. Merril)

\begin{tabular}{|c|c|c|c|c|}
\hline \multirow{2}{*}{ Perlakuan } & \multicolumn{4}{|c|}{ dosis POC Unitas Super $(\mathrm{ml} / 1)$} \\
\hline & 0 & 10 & 20 & 30 \\
\hline S0 & $97.67 \mathrm{Ba}$ & $91.33 \mathrm{Ca}$ & $99.33 \mathrm{Ba}$ & $106.33 \mathrm{Aa}$ \\
\hline S1 & $92.33 \mathrm{Ab}$ & $94.67 \mathrm{Aa}$ & $72.03 \mathrm{Bb}$ & $92.33 \mathrm{Ab}$ \\
\hline
\end{tabular}

Angka - angka pada baris yang sama diikuti oleh huruf besar yang sama dan pada kolom yang sama diikuti oleh huruf kecil yang sama berbeda tidak nyata menurut Uji DNMRT pada taraf 5\%.

Tabel 2. Pengaruh pemberian sediaan salut dan POC Unitas Super terhadap jumlah cabang pertanaman pada tanaman kedelai (Glycine max L. Merril)

\begin{tabular}{cccccc}
\hline Perlakuan & 0 & \multicolumn{5}{c}{ dosis POC Unitas Super (ml/1) } \\
\hline \multicolumn{7}{c}{10} & 20 & 30 \\
\hline S0 & --------------cabang-------------------- & \\
S1 & 29.00 & 24,70 & 23,00 & 23,70 \\
KK & 17.30 & 21,00 & 18,70 & 24,30 \\
\hline
\end{tabular}

Angka - angka pada kolom yang sama diikuti oleh huruf kecil yang sama berbeda tidak nyata menurut Uji Lanjut DNMRT pada taraf 5\%.

Tabel 2, memperlihatkan bahwa tanpa pemberian sediaan salut merupakan terbaik untuk meningkatkan jumlah cabang pada tanaman kedelai sebesar 5 buah cabang dibandingkan pemberian sediaan salut. Hal ini disebabkan karena dengan adanya pemberian $\mathrm{NH}_{4}^{+}$yang berlebihan pada sediaan salut $(1 \mathrm{~kg}$ Tanah + 1 kg Kompos + 100g Kapur $\mathrm{CaCO}_{3}+$ $0,5 \mathrm{~kg}$ Tanah Bekas Tanaman Kedelai $+10 \mathrm{~g}$ Pupuk Meroke Kaliphos) dapat menyebabkan terjadinya kerusakan akar karena didalam larutan tanah terjadi peningkatan fiksasi ammonium (Agustina L, 2004). Dengan demikian akan menghambat proses percabangan pada tanaman kedelai.
Pemberian pupuk organik cair Unitas Super tidak memberikan pengaruh yang nyata terhadap jumlah cabang pada tanaman kedelai. Akan tetapi, secara angka terlihat peningkatan dengan pemberian dosis $30 \mathrm{ml} / 1$ sebesar 0,8 dibandingkan pemberian dosis 0 $\mathrm{ml} / \mathrm{l}$. Hal ini disebabkan karena pemberian POC dapat meningkatkan jumlah klorofil (Jamilah et.al., 2008). Selanjutnya komposisi kandungan hara POC US makro 3,64\% N; $1,48 \% \mathrm{P} / 3,40 \% \mathrm{P}_{2} \mathrm{O}_{5}$ dan $2,01 \% \mathrm{~K}_{2} \mathrm{O}$. Maka dari itu, semakin tinggi pemberian pupuk organik cair Unitas Super maka akan meningkatkan jumlah cabang pada tanaman kedelai. 


\section{Jumlah Bintil Akar Efektif}

Hasil analisis sidik ragam perlakuan pengaruh sediaan salut dan organik cair memperlihatkan interaksi nyata terhadap jumlah bintil akar efektif , sedangkan perlakuan sediaan salut berpengaruh tidak nyata dan POC Unitas Super berpengaruh nyata terhadap jumlah bintil akar efektif seperti pada lampiran 5C . Jumlah bintil akar efektif disajikan pada Tabel 3.

Pada Tabel 3 dapat dilihat bahwa interaksi sediaan salut dan POC Unitas Super tidak berbeda nyata. Dimana tanpa pemberian sediaan salut dan $10 \mathrm{ml} / 1$ POC US merupakan interaksi terbaik untuk meningkatkan jumlah bintil akar efektif pada tanaman kedelai yaitu dengan jumlah bintil akar efektif 43,33 buah. Pada interaksi sediaan salut dan $20 \mathrm{ml} / 1$ POC US memberikan jumlah bintil akar efektif tertinggi, yaitu 31,33 buah. Tanpa pemberian salut memperlihatkan jumlah bintil akar efektif tertinggi dibanding perlakuan sediaan salut. Hal ini disebabkan karena sediaan salut telah mengandung unsur $\mathrm{N}$ yang lebih tinggi sehingga hal ini akan menyebabkan berkurangnya aktifitas dari bakteri bintil akar. Bintil akar akan efektif pada tanah yang kadar hara $\mathrm{N}$ nya rendah sebagaimana menurut Erawati et al (2013) bahwa peningkatan pemberian unsure $\mathrm{N}$ dari pupuk urea tidak signifikan meningkatkan jumlah bintil akar dan produksi kacang tanah.

Tabel 3. Pengaruh sediaan salut dan POC US Jumlah Bintil Akar Efektif tanaman kedelai (Glycine max L. Merril)

\begin{tabular}{|c|c|c|c|c|}
\hline \multirow{2}{*}{ Perlakuan } & \multicolumn{4}{|c|}{ dosis POC Unitas Super $(\mathrm{ml} / \mathrm{l})$} \\
\hline & 0 & 10 & 20 & 30 \\
\hline & & ...Buah & & \\
\hline S0 & $10.33 \mathrm{Cb}$ & $43.33 \mathrm{Aa}$ & $18.67 \mathrm{Bb}$ & $16.00 \mathrm{Bb}$ \\
\hline S1 & $19.67 \mathrm{Ba}$ & $14.00 \mathrm{Cb}$ & $31.33 \mathrm{Aa}$ & $21.33 \mathrm{Ba}$ \\
\hline KK & $13.06 \%$ & & & \\
\hline
\end{tabular}

Angka - angka pada baris yang sama diikuti oleh huruf besar yang sama dan pada kolom yang sama diikuti oleh huruf kecil yang sama berbeda tidak nyata menurut Uji Lanjut DNMRT pada taraf 5\%.

\section{Rasio Tajuk Akar}

Hasil analisis sidik ragam perlakuan sediaan salut dan pupuk organik cair tidak berinteraksi nyata, sedangkan sediaan salut tidak berpengaruh nyata terhadap rasio tajuk akar seperti pada lampiran 5D. Rasio tajuk akar pada tanaman kedelai disajikan pada Tabel 4.

Tabel 4. Pengaruh sediaan salut dan POC US terhadap Rasio Tajuk Akar tanaman kedelai (Glycine max L. Merril)

\begin{tabular}{ccccc}
\hline \multirow{2}{*}{ Perlakuan } & \multicolumn{4}{c}{ dosis POC Unitas Super $(\mathrm{ml} / \mathrm{l})$} \\
\cline { 2 - 5 } & \multicolumn{5}{c}{10} & 20 & 30 \\
\cline { 2 - 5 } S0 & 9.72 & 10.66 & 14.17 & 13.22 \\
S1 & 8.12 & 12.76 & 10.54 & 15.15 \\
\hline KK & $20.81 \%$ & & \\
\hline Angka - angka pada baris diikuti oleh huruf & besar yang sama & berbeda tidak nyata menurut Uji Lanjut \\
DNMRT pada taraf 5\%. & & &
\end{tabular}


Pada tabel 4 memperlihatkan bahwa pemberian dosis $30 \mathrm{ml} / 1$ POC Unitas Super memiliki rasio tajuk dan akar tertinggi yaitu 14.18. Semakin menurunnya dosis POC US yang diberikan memperlihatkan penurunan rasio tajuk akar. Hal ini menjelaskan bahwa dosis POC Unitas Super $30 \mathrm{ml} / 1 \mathrm{mampu}$ menyediakan unsure hara bagi tanaman, sehingga hal ini akan meningkatkan ratio tajuk akar. Sebagaimana menurut Jamilah (2005) bahwa kandungan POC US terbuat dari $C$. odorata, sabut kelapa dan MOL (Mikroorganisme Lokal), dimana $C$. odorata memiliki keunikan tersendiri selain dapat berkembang dengan cepat, gulma ini juga mampu tumbuh dilahan marginal dan miskin air serta perkembangan akar.

Tabel 4. Juga menunjukkan pemberian sediaan salut berpengaruh tidak nyata terhadap rasio tajuk akar pada tanaman kedelai. Akan tetapi secara angka terjadinya perbedaan antara tanpa sedian salut (kontrol) dengan sediaan salut . Hal ini diduga karena perbedaan keduanya sehingga tidak memberikan pengaruh terhadap rasio tajuk akar tanaman kedelai.
Kandungan $\mathrm{NH}_{4}^{+}$dalam jumlah yang berlebihan didalam tanah dapat menyebabkan kerusakan pada akar tanaman. Dimana, reaksi penyerapan $\mathrm{O}_{2}$ untuk metabolisme nitrogen dalm sel tanaman tiga kali lebih tinggi pada $\mathrm{NH}_{4}{ }^{+}$dibandingkan $\mathrm{NO}_{3}{ }^{-}$dan terjadi respirasi yang tinggi, sehingga membutuhkan $\mathrm{O}_{2}$ yang tinggi. Dengan demikian $\mathrm{O}_{2}$ dapat menjadi faktor pembatas jika kurang tersedia dan reduksi $\mathrm{NH}_{4}^{+}$menjadi $\mathrm{NH}_{3}$ yang cepat dan hampir seluruh direduksi dalam akar, mengakibatkan penipisan cadangan karbohidrat dalam akar (Neumann dan Kafkafi cit Hasiolan, 2010).

\section{E. Persentase Polong Bernas}

Hasil sidik ragam perlakuan sediaan salut dan pupuk organik cair memperlihatkan interaksi nyata terhadap persentase polong bernas. Sedangkan perlakuaan sediaan salut berpengaruh nyata dan pupuk organik cair berpengaruh nyata terhadap persentase polong bernas seperti terlihat pada lampiran 5E. Persentase polong bernas disajikan pada Tabel 5 .

Tabel 5. Pengaruh pemberian sediaan salut dan POC US terhadap persentase polong bernas pada tanaman kedelai (Glycine max L. Merril)

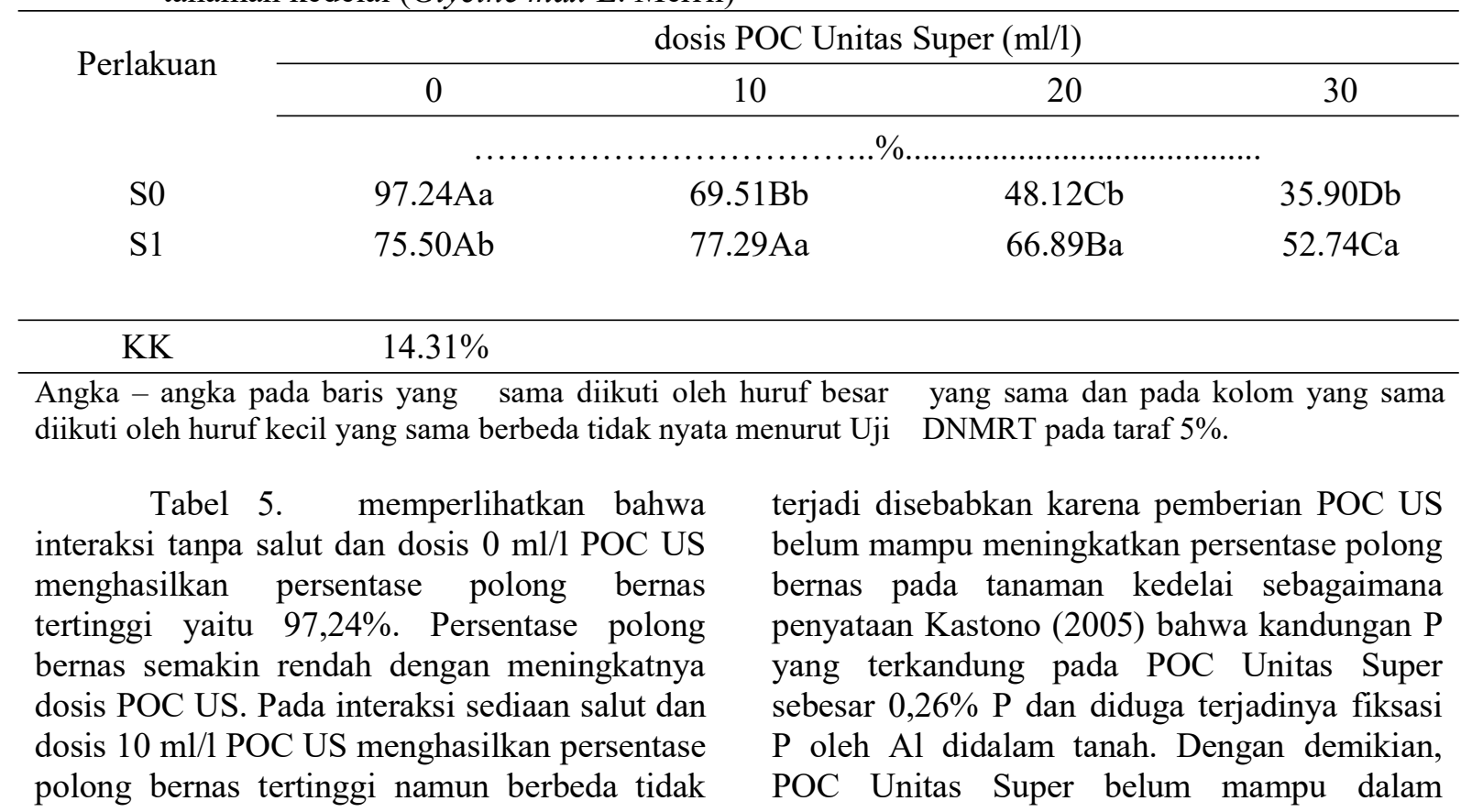


meningkatkan persentase polong bernas pada tanaman kedelai.

\section{F. Bobot 100 Biji}

Hasil analisis sidik ragam perlakuan sediaan salut dan pupuk organik cair memperlihatkan tidak berinteraksinyata terhadap bobot 100 biji, sedangkan perlakuan sediaan salut berpengaruh nyata dan pupuk organik cair tidak berpengaruh nyata terhadap bobot 100 biji seperti pada lampiran 5F. Hasil pengamatan bobot 100 biji pada tanaman kedelai disajikan pada Tabel 6 .

Tabel 6. Pengaruh pemberian sediaan salut dan POC Unitas Super terhadap bobot 100 biji pada tanaman kedelai (Glycine max L. Merril)

\begin{tabular}{|c|c|c|c|c|}
\hline \multirow{2}{*}{ Perlakuan } & \multicolumn{4}{|c|}{ dosis POC Unitas Super (ml/1) } \\
\hline & 0 & 10 & 20 & 30 \\
\hline & & …… & ….... & ...... \\
\hline S0 & 17.15 & 16.64 & 15.29 & 15.15 \\
\hline S1 & 15.02 & 12.72 & 12.15 & 12.43 \\
\hline
\end{tabular}

KK $13.68 \%$

Angka - angka pada kolom yang sama diikuti oleh huruf kecil yang sama berbeda tidak nyata menurut Uji Lanjut DNMRT pada taraf 5\%.

Tabel 6. memperlihatkan bahwa tanpa pemberian sediaan salut merupakan terbaik dalam meningkatkan bobot 100 biji pada tanaman kedelai, sebesar $2,72 \mathrm{~g}$ dibandingkan pemberian sediaan salut. Hal ini disebabkan karena pada tanaman kedelai yang dibudidayakan didataran tinggi menyebabkan $\mathrm{NO}_{3}{ }^{-}$tinggi, sehingga mempengaruhi bintil akar serta aktifitas fiksasi $\mathrm{N}$, dimana $\mathrm{NO}_{3}{ }^{-}$dapat menghancurkan bintil akar (Sudarno,2002).

Peningkatkan dosis POC US tidak mempengaruhi bobot 100 biji pada tanaman kedelai. Hal ini disebabkan kandungan $\mathrm{P}$ yang terkandung pada POC US sebesar 0,26\% P
(Kastono, 2005) dan diduga terjadinya fiksasi $\mathrm{P}$ oleh Al didalam tanah. Dengan demikian, POC Unitas Super belum mampu dalam meningkatkan persentase polong berbobot 100 biji pada tanaman kedelai.

\section{G. Berat pipilan kering per tanaman}

Hasil analisis sidik ragam perlakuan sediaan salut dan pupuk organik cair memperlihatkan interaksi nyata terhadap berat pipilan kering tanaman kedelai (Glycine max L. Merril) seperti pada lampiran 5G. Berat pipilan kering per tanaman disajikan pada Tabel 7.

Tabel 7. Pengaruh pemberian sediaan salut dan POC US terhadap berat pipilan kering per tanaman kedelai (Glycine max L. Merril)

Perlakuan dosis POC Unitas Super $(\mathrm{ml} / \mathrm{l})$

\begin{tabular}{lcccc} 
& 0 & 10 & 20 & 30 \\
\cline { 2 - 5 } & & & & \\
S0 & $19,83 \mathrm{Ab}$ & $20,07 \mathrm{Aa}$ & $13,50 \mathrm{Bb}$ & $17,47 \mathrm{Aa}$ \\
S1 & $24,57 \mathrm{Aa}$ & $14,50 \mathrm{Bb}$ & $17,73 \mathrm{Ba}$ & $15,60 \mathrm{Ba}$
\end{tabular}

KK

$10,26 \%$

Angka - angka pada baris yang sama diikuti oleh huruf besar yang sama dan pada kolom yang sama diikuti oleh huruf kecil yang sama berbeda tidak nyata menurut Uji Lanjut DNMRT pada taraf 5\%. 
Tabel 7. memperlihatkan bahwa interaksi pemberian sediaan salut dan $0 \mathrm{ml} / \mathrm{l}$ POC US menghasilkan berat pipilan kering per polybag tertinggi yaitu 24,57 g. Tanpa pemberian sediaaan salut dan $10 \mathrm{ml} / 1$ POC US merupakan interaksi terbaik meningkatkan berat pipilan kering per polybag pada tanaman kedelai yaitu 20,07 g, namun berbeda tidak nyata dengan interaksi $0 \mathrm{ml} / 1$ POC US.

Bobot pipilan kering per tanaman juga ditentukan oleh persentase polong bernas pada tabel, dimana persentase polong bernas tertinggi adalah pada interaksi tanpa sediaan salut dan $0 \mathrm{ml} / 1$ POC US.

\section{KESIMPULAN}

Berdasarkan hasil penelitian mengenai pengaruh sediaan salut dan pupuk organik cair unitas super terhadap pertumbuhan dan hasil produksi tanaman kedelai maka dapat disimpulkan bahwa : Adanya interaksi antara sediaan salut dengan POC terhadap pertumbuhan dan hasil kedelai seperti tinggi tanaman, serta Pemberian $10 \mathrm{ml} / 1$ POC US dengan $0 \mathrm{~g}$ salut memberikan hasil biji kering kedelai tertinggi mencapai 20,07 g/tanaman. Jika benih kedelai diberi sediaan salut maka pemberian $0 \mathrm{ml} / 1$ POC memberi hasil tertinggi mencapai $24,57 \mathrm{~g} /$ tanaman.

\section{DAFTAR PUSTAKA}

Adisarwanto.T. 2004. Strategi Peningkatan Produksi Kedelai Sebagai Upaya Untuk Memenuhi Kebutuhan Dalam Negeri Dan Mengurangi Impor.. Penerbit Swadaya. Jakarta.

Agustina. L. 2004. Dasar Nutrisi Tanaman . Rineka Cipta Jakarta.

Andrianto dan Indarto. 2004. Budidaya dan Analisis Usaha Tani Kedelai. Kacang Hijau dan Kacang Tanah. Absolut. Jogyakarta.

Anonimous, 2004 a. Dukungan Inovasi Teknologi dan Program Bangkit Kedelai . Puslitbangtan. Makalah disampaikan pada Bagkit Kedelai di Cisarua.

Anonim.2017. Nama-nama Varietas kedelai unggulan Indonesia. Berita Sampul Pertanian.http :// www.sampul pertanian.com/2017/05/nama-nama varietas kedelai unggulan -di.html, diakses tanggal 31 Oktober 2017.

Azevedo,Azevedo JL.2014. Endophytic fungi Brazilian tropical hosts and their biotechnological. In:Khawar RN, Upadhyay R, Dubey N, Raghuwanshi $\mathrm{R}$, editors. Microbial Diversity and Biotechnology in Food Securrity.India : Springer; 2014.p.17486

Baker S, Satish S. 2012.Endophytes : Natural warehouse of bioactive compounds.Drug Invent Today ;4(11):548-533

BPS. 2016. Produktivitas Kedelai. https://data.go.id/dataset/tanaman kacang-kedelai-per-provinsi2/resource/3e70120a-f4c0-4396-9c63300df6b19 a1, diakses tanggal 31 Oktober 2017.

Chairunas.(2012). Pendampingan Program Strategis Kementrian Pertanian S1Ptt Kedelai.(K.Pertanian, Ed.)( $1^{\text {st }}$ ed).Aceh: Balai Pengkajian Teknologi Pertanian Aceh.

Ernita,M. Zaharnis, Jamilah. 2016. Aplikasi rhizobakteri terhadap ketahanan dan produksi tanaman bawang merah. Jurnal Pengabdian pada Masyarakat, UNIMED, Medan, Vol 2(3):10-19.

Fernandes, E.G.,Pereira, O L., Silva, C.C. da, Bento, C.B.P.,\&Queriroz, M.V. de.(2015).Diversity of endophytic fungi in Glycine max.Microbiological Research, 181, 84- 
92.https://doi.org/10.1016/j.micres.201 $\underline{5.05 .010}$

Hakim.2006.Pengelolaan Kesuburan Tanah Masam dengan Teknologi Pengapuran Terpadu. Andalas University Press Padang.240 hal.

Hardjowigeno, S.2003.Ilmu Tanah Jakarta Akademika Presindo 285 hal.

Hasiolan, S.B.Supriati : Isjwara, RM, 2010 Pengaruh Perbandingan Nitrat sama Amonium terhadap Pertumbuhan dan Hasil Tanaman Selada (Lactusa Sativa L) yang dibudidayakan Secara Hidroponik. Seminar Pengembangan Teknologi Hortikultura UKSW Salatiga .43 hal

Heide, B. Van Der.(2004). Pengelolaan Kesuburan Lahan Kering Masam Untuk Kedelai, 50(7), 39-50.

James, M.S. (2015). Effects of Biochar-Based Seed Coatings on Seed Germination and Seedling Vigor of California Brome (Bromus carinatus L.) and Blue Wildrye (Elymus glaucus

L.)Abstract.Oregon.

Jamilah.(2016). Pengaruh Pupuk Organik Cair Asal C. odorata Terhadap Serapan Hara Kalium Dan Hasil Padi Ladang. Jurnal Bibiet, ISSN 25020951, 1(1), 17-26. https://doi.org/http://dx.doi.org/10. 22216/jbbt.vlil.258.

Jamilah, Fadhila, R., Mulyani, S. (2017). Farm analysis of rice crop trimmed periodically in the tropical wet. In International Conerence on Social,Humanitiesand Government Science Vol.1,p.631) .https: //doi.org/10.1016/S09694765(04)00066-9
Jamilah \&Helmawati (2015).Kajian Analisis Usaha Tani Integrasi Padi Sawah dan Pakan Ternak Ruminansia Menunjang Kedaulatan Pangan dan Daging Agriculture: Nutrient Uptake of Organic versus Mineral Fertilizers in Citrus Trees, 120.https://doi.org/10.1371/journal. pone.0161619

Mei et al., 2012 Mei WL, Zheng B, Zhao B, Zhao YX, Zhong HM, Chen XLW, Zeng YB, Dong WH, Huang JL, Proksch P, Dai HF. Meroterpenes from endophytic fungus $\mathrm{Al}$ of mangrove plant Scyphiphora hydrophyllacea. Mar Drugs 2012 ; 10:1993-2001, http://dx.doi.org/10.3390/md 10091993

Pitojo.S.1995.Penggunaan Urea Tablet PT.Penebar Swadaya Jakarta.61 hal.

Purwono dan Heni Purnawati 2013.Budidaya 8 Jenis Tanaman Pangan Unggul.Penebar Swadaya.Jakarta.

Sudarno, H.Rusin, Marjono dan Supri.2002.Pengaruh Sumber Nitrogen, Dosis, dan Waktu Pemberian Terhadap Produksi dan Mutu Benih Jarak Didalam Proseding Seminar Pengembangan Wilayah dalam Rangka Otonomi Daerah.16 Oktober 2002.Malang.

Suprapto,2002.Kedelai Penebar Swadaya.Jakarta.

Widodo.2004.Pertumbuhan dan Hasil Padi Gogo CV Cirata terhadap 3 jenis Media Tanam dan Ukuran Pupuk Urea. Akta Agrosir.Vol 7 No.1:6-10 